\title{
"The mechanism of higher education funding in Ukraine: nationwide and local perspective"
}

\begin{tabular}{|c|c|}
\hline \multirow{5}{*}{ AUTHORS } & Iryna Degtyarova (D https://orcid.org/0000-0003-4298-5488 \\
\hline & Olha Hryhorash (D https://orcid.org/0000-0002-8089-3755 \\
\hline & $\mathbb{R}$ https://publons.com/researcher/1976980/olha-v-hryhorash/ \\
\hline & Victor Chentsov (D https://orcid.org/0000-0002-1109-8168 \\
\hline & $\mathbb{R}$ https://publons.com/researcher/1875835/victor-v-chentsov/ \\
\hline ARTICLE INFO & $\begin{array}{l}\text { Iryna Degtyarova, Olha Hryhorash and Victor Chentsov (2018). The mechanism } \\
\text { of higher education funding in Ukraine: nationwide and local perspective. } \\
\text { Investment Management and Financial Innovations, 15(3), 223-236. } \\
\text { doi:10.21511/imfi.15(3).2018.19 }\end{array}$ \\
\hline DOI & http://dx.doi.org/10.21511/imfi.15(3).2018.19 \\
\hline RELEASED ON & Friday, 07 September 2018 \\
\hline RECEIVED ON & Saturday, 30 June 2018 \\
\hline \multirow[t]{2}{*}{ ACCEPTED ON } & Tuesday, 14 August 2018 \\
\hline & $((c))_{E Y}$ \\
\hline LICENSE & $\begin{array}{l}\text { This work is licensed under a Creative Commons Attribution } 4.0 \text { International } \\
\text { License }\end{array}$ \\
\hline JOURNAL & "Investment Management and Financial Innovations" \\
\hline ISSN PRINT & $1810-4967$ \\
\hline ISSN ONLINE & $1812-9358$ \\
\hline PUBLISHER & LLC "Consulting Publishing Company "Business Perspectives" \\
\hline FOUNDER & LLC “Consulting Publishing Company "Business Perspectives" \\
\hline
\end{tabular}

NUMBER OF REFERENCES

37

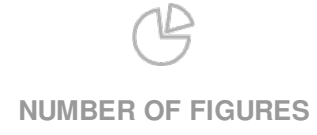

4

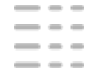

NUMBER OF TABLES

4

(C) The author(s) 2021. This publication is an open access article. 


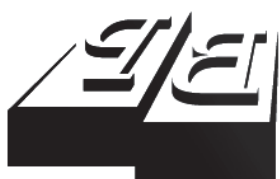

BUSINESS PERSPECTIVES

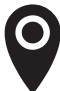

LLC "CPC "Business Perspectives" Hryhorii Skovoroda lane, 10, Sumy, 40022, Ukraine

www.businessperspectives.org

Received on: $30^{\text {th }}$ of June, 2018 Accepted on: $14^{\text {th }}$ of August, 2018

(C) Iryna Degtyarova, Olha Hryhorash, Victor Chentsov, 2018

Iryna Degtyarova, Ph.D. (Linguistics), Adjunct Researcher, Polish Rectors Foundation - Institute of Knowledge Society; Doctoral Candidate (Public Policy), Warsaw School of Economics, Poland.

Olha Hryhorash, Ph.D, (Economics), Senior Lecturer, Department of Finance of Business Entities and Insurance, University of Customs and Finance, Ukraine.

Victor Chentsov, D.Sc. (History), D.Sc. (Public Management and Administration), First Vice-Rector, University of Customs and Finance, Ukraine.

\section{(ㄷ) (i)}

This is an Open Access article, distributed under the terms of the Creative Commons Attribution 4.0 International license, which permits unrestricted re-use, distribution, and reproduction in any medium, provided the original work is properly cited.

\section{THE MECHANISM OF HIGHER EDUCATION FUNDING IN UKRAINE: NATIONWIDE AND LOCAL PERSPECTIVE}

\begin{abstract}
Despite positive transformations in higher education in Ukraine since 2014 when a new Law was introduced, the system of public funding still remains a highly centralized and strongly budgetary dependent based on the state planning methods, which in the situation of lack of resources becomes more imbalanced and inefficient.

The current system of allocation of the "state order for training the specialists with higher education" does not ensure an equal and fair competition among top 10 universities and the rest, especially regional, and the system cannot guarantee state-funded places to all applicants with high results of the External Independent Testing exams. At the same time, only a small share of graduates work on the specialty they acquired. The situation on the labor market does not encourage graduates to be employed in public institutions, which is harmful for the public sector of economy, especially in the regions. It proves that the system of distribution and allocation of government funding between higher education institutions in Ukraine needs urgent reforming.

The objective is to analyze the current system of higher education funding in Ukraine in its national dimension and local perspective, and to develop proposals for its improvement, considering the selected good practices and using the following methods: literature analysis, method of retrospective analysis to research budgetary expenditures, determining the Net Present Value for calculating the government cost. Finally, a feasible proposal to reform the mechanism of public higher education funding was developed.
\end{abstract}

Keywords

higher education, public funding, state order, student loans

\section{JEL Classification I22}

\section{INTRODUCTION}

Ukraine is one of the countries with a high potential of human resources proved by global rankings and at the same time weak positioning of economy. According to the ranking of International Human Capital Development Index by UNDP, in 2015, Ukraine was classified as a country with a high level of human development (Ukraine ranks $84^{\text {th }}$ in the range of 52-102 places). The general level of population literacy in the age under 15 years was $99.8 \%$; in particular, $82 \%$ of the population have higher education. Budget expenditures for education were 6.7\% of GDP (Human Development Statistical Tables, 2016).

World Economic Forum in the Global Human Capital Index 2017 put Ukraine in the $24^{\text {th }}$ place (overall ranking) between Great Britain and Lithuania, stressing that "Ukraine's performance is particularly high relative to its GDP per capita levels" (The Global Human Capital Report, 2017). However, rankings of Ukraine connected with GDP and economic situation appear to be lower: by 2017, GDP of Ukraine is on the $60^{\text {th }}$ place between Sudan and Morocco, while GDP PPP is on the $47^{\text {th }}$ place between Czech Republic and Ireland (New country classifications by income level, 2018). We assume that the human capital 
and its potential are not used efficiently for ensuring the economic growth in Ukraine, mostly because of the complicated heritage of "command mode of economic management, a government as a main customer of educational services" (Bagmet \& Liakhovets, 2017), inhibiting development of education for the knowledge economy.

Higher Education Institutions (HEIs) in Ukraine have one of the weakest financial autonomy, which is very limited in terms of attracting and spending funds. The European University Association (EUA) in 2015 defined the major challenges in Ukrainian system of higher education, which are "inadequate funding modalities", "critically low level of public funding for higher education", "unbalanced income sources for universities" (Athena, 2015). EUA recommendations strongly advised to reform the system of a "state order" as a mechanism of public higher education funding in Ukraine.

Against the improving quality of education and increasing requirements to universities, the total amount of state order for training the students has been decreasing. In spite of the reports that the distribution and allocation of state-funded places should be done according to the principles of transparency, balanced and harmonized development, the real situation and admission results prove the contrary. The final amount of state order for HEIs is formed by the results of an open admission competition, but in reality the major part of state-funded places concentrates in HEIs located in the capital city (universities located in Kyiv). Moreover, Kyiv universities have sufficient number of students paying tuition fees that exceeds public funding and in fact they could develop and operate successfully even without constantly increasing state order, especially at the cost of budgetary places in smaller universities. No doubt, the best universities should get exceptional support and more funding from the government in order to develop world class research universities (Satsyk, 2014), but not at the cost of weakening the others. The leading universities cannot compete with the smaller regional or local universities, and public funding cannot be redistributed from regional to central HEIs, as they function in different conditions.

Taking into account such imbalance and disproportions in Ukraine, there is a need to bring the existing system of higher education funding to current realities, considering both students' needs, universities and government interests, and taking into account the significance of the regional and local higher education landscape, as well as aiming at the priority of balanced economic growth.

\section{THE OVERVIEW}

\section{OF THE PUBLIC HIGHER EDUCATION FUNDING MODELS: LITERATURE ANALYSIS}

The issues of university funding, challenges and perspectives of higher education development, as well as its efficiency and effectiveness for social and economic development, are crucial in all countries and being discussed and studied on the European level as well. Financial issues became more important after global economic crises; the universities also faced a number of challenges connected with the decrease of public funding.
The global higher education landscape shows multiple mechanisms of public higher education funding. EUA's Public Funding Observatory demonstrates a big diversity of the funding schemes according to the national framework. There are four main models of public funding in higher education (see Figure 1): block grant (performancebased funding, formula-based funding), projectbased funding, excellence-finding schemes, direct and targeted funding (Pruvot et al., 2015).

In the EU countries almost $80 \%$ of funding for higher education come from public sources (Eurydice, Higher education governance in Europe, 2008) through various mechanisms: budget negotiation with the funding body based on a budget estimate submitted by the institution; bud- 
BLOCK GRANT

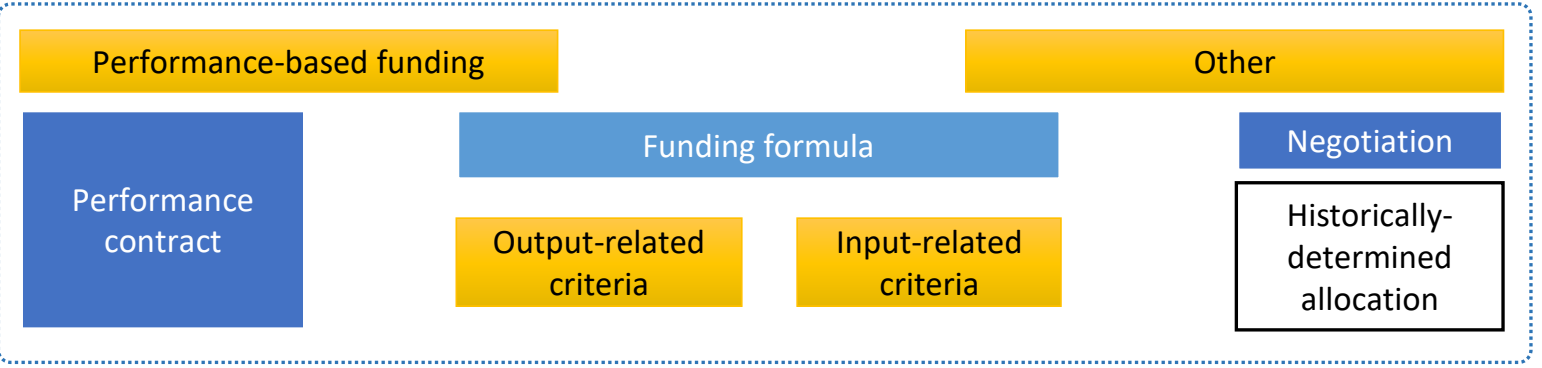

Project-based funding

Funding for excellence

Other direct funding (including target funding)

Figure 1. Variety of public funding allocation mechanisms

get established by the funding body based on past costs; funding formula; performance contracts based on strategic objectives; contracts based on a predetermined number of graduates by field of study; funding for specific research projects, awarded in the framework of competitive bidding procedures; budget negotiation with the funding body based on a budget estimate submitted by the institution.

Jongbloed (2004) overviews four major trends in higher education funding:

1) traditional, centralized type of funding (planned, input-based funding through providers, negotiated funding);

2) performance-based funding of providers;

3) purpose-specific purchasing from providers;

4) demand-driven, input-based funding through clients, voucher system.

So the funding mechanisms can be described as budget-oriented, program-oriented, student-centred, and supply-driven. Following the ideas by Jongbloed, in order to define an appropriate funding model for higher education system, the governments should consider some key issues: costs and benefits balance for all stakeholders (students, government, business, universities, local commu- nities, etc.); the model of funding should allow for a more diverse higher education system with varied institutions and programs; special support for the programs that have an important social or cultural value needs to be guaranteed; funding mechanisms should not erect financial barriers for qualified students to enrol in the institution of their own choice. We are concerned that those selected conditions are the most important for reforming the public funding in Ukraine.

Undoubtedly, no ideal model fit for all and ready to transfer can be found. Lepori (2007) stresses that "choice between allocation models is essentially a matter of political choice about the goals to be achieved and the wished configuration of the higher education system". Applying this idea as a starting point for our study, an efficient use of budgetary funds, employment and development of public sector of economy could become priorities for Ukraine.

What is important nowadays is that higher education is considered crucial for economic development and building a welfare state being its part and precondition (Kwiek, 2006; United Nations, OECD, World Economic Forum documents). The economic growth is boosted by the effective education and development of the upcoming management workforce across Europe (O'Leary, 2015), and free market should be an important actor affecting the trends of demand and supply (Cohen \& Davidovitch, 2015). 
Carton, McMillan, and Overall (2018) argue that the global expansion of higher education needs to be considered in higher education development. Enhancing the academic capacity of universities is closely connected with increasing their impact on the local economic development. The governments should change their mind in developing public funding mechanisms and consider education spending models rather as a state investment, not a cost or social expenditure (Kwiek, 2006), so the government "acts as a public investor in the field of higher education on behalf of taxpayers, and it imposes on them a duty to supervise the fulfilment of constitutional principles by universities (legality, feasibility, accountability, expediency) (Woźnicki, 2017). The policy in higher education system should be shifted from the funding issues itself to quality assurance and efficient quality management, which can help to minimize a negative impact of bureaucratic management on the competitiveness of a modern university (O. Velichko \& L. Velichko, 2018). Especially it is important in terms of limited resources in postcommunist economies in developing countries (Penceliah, Konyana, \& Maharaj, 2016).

The idea of diversification of the public funding in higher education by introducing the schemes of student loans is promoted by experts of the World Bank (Salmi, 2003). It is important to reform student aid schemes by "creation of public credit market of education, in order to finance students' cost of living and sometimes tuition fees by some specific loans to students" (Guille, 2002).

The model of student loans is widely used in many countries (USA, UK, Sweden, Norway, the Netherlands, Germany, Poland, etc.), and the loans are not considered as consumer credits and do not have a commercial nature either, but are regulated by their unique legal framework and requirements. E.g., in Poland, public funding for full-time higher education in public universities for Polish citizens is guaranteed by the Constitution, but at the same time the system of student loans is created and tuition fees are allowed for part-time students and foreigners. The system of student loans in Poland was introduced in 1998. The loans are given by the selected commercial banks (by the agreement with the National Bank (BGK) and with a share of government co-financing. Graduates start repayments in two years after graduation, and flexible condi- tions, income criteria, possibility of suspension or forgiveness are guaranteed by the Law (The Act on Higher Education and Science, 2018). What's important is that one of the conditions for repayment forgiveness is excellence of learning, which proves the necessity of correlation between funding and quality of education.

In the USA, varied schemes of students' loans are the major source of higher education funding, along with the public programs of loan forgiveness (for teachers, in case of death, disability, bankruptcy, etc.). Special focus should be made on a new program "The Public Service Loan Forgiveness (PSLF)" established in 2015, which enables forgiveness of the student loan debt if the person is employed full-time in public service by the so called qualifying public or non-profit entity (Public Service Loan Forgiveness, n.d.). The government defined the qualifying employers: government organizations at any level (federal, state, local, or tribal), not-for-profit organizations if providing public services, AmeriCorps or Peace Corps. But the other formal requirement is the repayment of the loan for 120 months, no matter consecutive or not, except for those who are on a military service (they can be eligible for the program after 12 month payment). This is a good practice and example for Ukraine how to reward student loans borrowers for serving the public services and at the same time to encourage the best graduates to work in public institutions, and if necessary to introduce support of military servants.

In Ukraine, the current model of higher education funding is multi-source funding (considering big share of tuition fees), but it must be reformed based on "the principles of real academic autonomy, university fundraising and good governance" both on the systemic level (good practices of public funding) and the institutional one (university financial management) (Borodin, Prokopenko, \& Degtyarova, 2013). During the last decade, Ukrainian researchers proposed a number of ideas to reform the system of higher education, in particular public funding. Many researchers consider that block grant or performance-based funding model should replace "state order" and legal status of HIEs, as state budgetary institutions should be changed to allow more autonomy and freedom in terms of financial operation (Stadny, 2016) or a voucher-type funding model in higher education 
could also be introduced (Higher Education in Ukraine: Agenda for reforms, 2017).

Rybchanska (2016) appraises the financial leverage of higher education development level in Ukraine, Savchenko and Chumak (2017) develop a model for higher education reforming in the context of improving the state mechanism for higher education funding, Shevchuk (2014) suggests using the foreign experience in managing the development of regional educational systems in Ukraine, Zatonatskaya (2012) considers different forms of higher education funding in different countries of the world and the prospects of using the similar experience in Ukraine.

The issue of the effectiveness and efficiency of allocation of state-funded places for training the specialists with higher education is at the heart of the government's interest. In particular, on July 5, 2018, the Ministry of Economic Development proposed some significant changes to the mechanism of state budgetary funding for public Higher Education Institutions (The Ministry of Economic Development and Trade of Ukraine, 2018). In particular, a state order mechanism and allocation model should be urgently changed, and it must take into account the real needs of the labor market, as well the system of graduates tracking needs to be developed and introduced in order to monitor the employment of university graduates by different specialties and fields of economic activity.

So the efficiency of state order mechanism and distribution of government-funded places, and the reasonability of the budgetary expenditures allocation require a deeper and broader analysis from the perspective of the local labor market and economic growth.

\section{RESEARCH FINDINGS} AND PROPOSAL OF A NEW
MODEL OF PUBLIC HIGHER
EDUCATION FUNDING
IN UKRAINE

The system of public higher education funding in Ukraine is based on the government funding program and state order mechanism, which can be characterized as direct government funding (line items) with partial use of formula-based approach, and the principle "money after student". Both national and European experts agree that funding mechanism of state order in Ukraine needs to be reformed. European University Association (EUA) suggested some measures for Ukraine (Athena, 2015, p. 38):

1. to update the modalities through which public funding is dispensed:

b. remove line-item budgets [replace with block grants];

c. introduce a modern cost weighting system using some output criteria;

2. to give universities more freedom to set tuition fees for fee-paying students, in particular international students (combine with appropriate student support system).

Ukraine should "develop a long-term plan for investing in higher education", which means creating a clear vision of higher education funding in Ukraine.

The annual changes in the admission regulations and legal frameworks, which have to make the university admission process easier or make its performance more efficient, do not lead to positive changes, but even destabilize them. The increasing requirements to universities and at the same time decline of the amount of government-funded places seriously hinder the possibilities for gifted youth to get higher education in regional or local HEIs.

According to national legislation, par. 3 of Art. 71 of the Law of Ukraine "On Higher Education" (adopted on July 1, 2014, No. 1556-VII), the amount of budget expenditures on higher education is defined in the Law "On State Budget" for the corresponding year. The state order allocation is carried out on a competitive basis, adhering to the principles of fair competition, openness and transparency, equality, objective and unbiased evaluation of bidders' proposals (art. 72).

Against the background of refocusing the system of higher education from educational institutions 
Table 1. The dynamics of budget expenditures on higher education in the period 2012-2017

Source: Developed by the authors based on State Treasury Service of Ukraine (n.d.), Expenditures on the program classification of expenditures and lending of the state budget, State Statistics Service of Ukraine (n.d.), Consumer price index).

\begin{tabular}{|c|c|c|c|c|c|c|c|c|}
\hline \multirow[b]{2}{*}{ Indicators } & \multirow[b]{2}{*}{2012} & \multirow[b]{2}{*}{2013} & \multirow[b]{2}{*}{2014} & \multirow[b]{2}{*}{2015} & \multirow[b]{2}{*}{2016} & \multirow[b]{2}{*}{2017} & \multicolumn{2}{|c|}{ Variance $2017 / 2012$} \\
\hline & & & & & & & $\begin{array}{l}\text { Abs } \\
\text { UAH bill }\end{array}$ & $\underset{\%}{\text { Percentage, }}$ \\
\hline $\begin{array}{l}\text { Training specialists with higher education by HEls } \\
\text { of the III and IV accreditation levels and their } \\
\text { maintenance, UAH billion }\end{array}$ & 15,1 & 15,8 & 15,0 & 17,7 & 20,0 & 20,3 & 5,2 & 34.4 \\
\hline $\begin{array}{l}\text { Training specialists with higher education by HEIs } \\
\text { of the III and IV accreditation levels and their } \\
\text { maintenance (adjusted for inflation index), UAH } \\
\text { billion }\end{array}$ & 15,2 & 15,8 & 12,0 & 12,4 & 17,8 & 17,9 & 2,7 & 18.0 \\
\hline $\begin{array}{l}\text { Training specialists with higher education by Taras } \\
\text { Shevchenko National University of Kyiv and its } \\
\text { maintenance, UAH billion }\end{array}$ & 0,86 & 0,88 & 0,85 & 0,91 & 1,02 & 1,22 & 0,4 & 41.1 \\
\hline $\begin{array}{l}\text { Training the specialists with higher education by } \\
\text { Taras Shevchenko National University of Kyiv and } \\
\text { its maintenance (adjusted for inflation index), UAH } \\
\text { billion }\end{array}$ & 0,87 & 0,88 & 0,68 & 0,64 & 0,91 & 1,07 & 0,2 & 23.9 \\
\hline
\end{tabular}

funding to the student-centred one, public Higher Education Institutions are funded from the state budget on the basis of state order for training specialists with higher education and research workers, as well as from other sources not prohibited by the law, provided that this is done with adherence to the principles of targeted and effective use of allocated funds, publicity and transparent in the decision making (art. 71, par. 1).

It should be noted that the whole public funding for higher education includes some separate lines in the budgetary law: direct line funding for Taras Shevchenko National University of Kyiv, direct line funding for doctoral training in National Academy of Sciences, and block funding for all public (state) HEIs. So let's analyze the budget expenditures for higher education funding in Ukraine (Table 1).

According to Table 1, we can conclude that the budget expenditures for training specialists with higher education by HEIs of the III-IV accreditation levels and their maintenance during the period 2012-2017 have increased in absolute numbers by 34.4\%: from UAH 15,1 billion to UAH 20,3 billion. Therefore, in fact, taking into account the inflation index, budget expenditures for HEIs funding have increased only by $18.0 \%$. At the same time, real ex-

Source: Developed by the authors based on State Statistics Service of Ukraine (n.d.), Higher educational institutions (2012-2017).

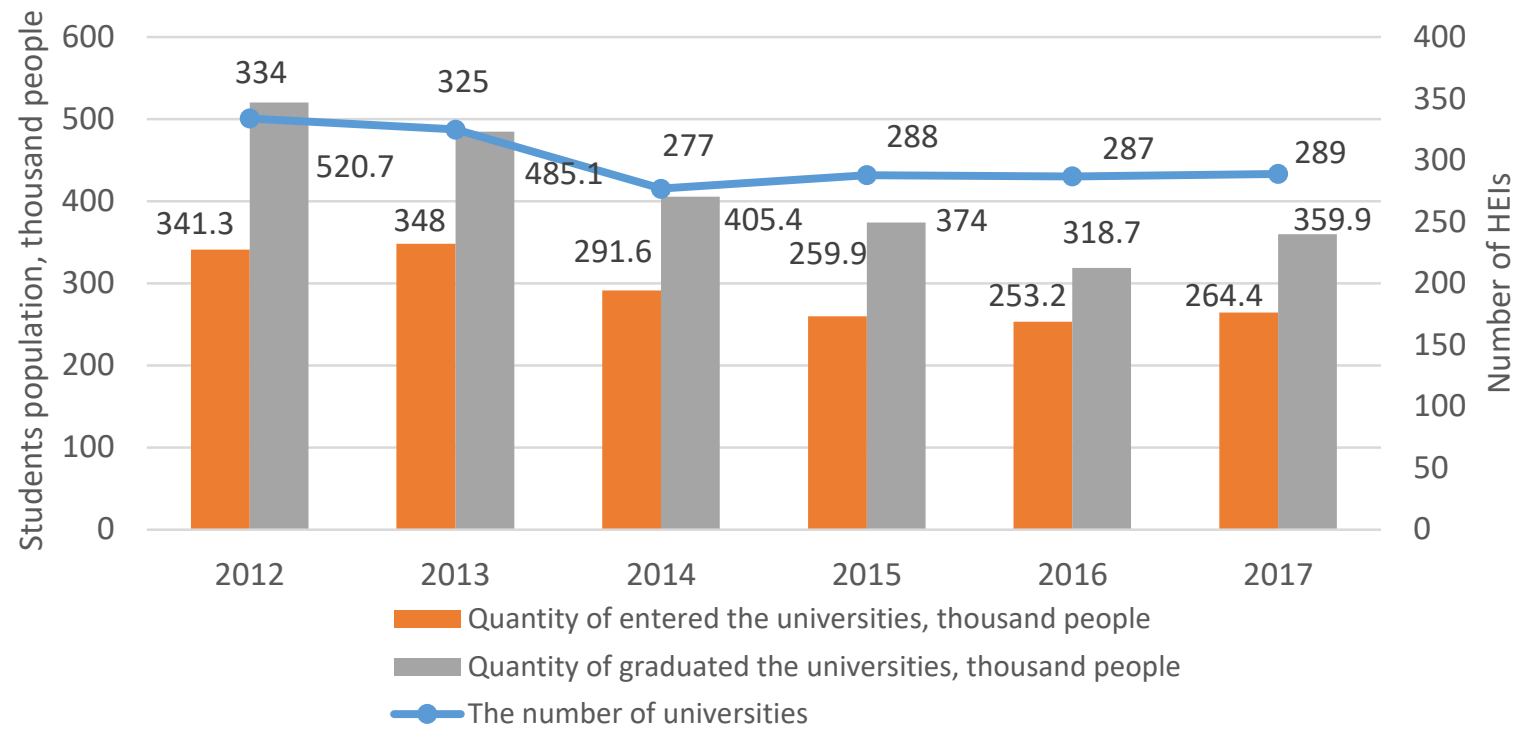

Figure 2. The enrolment and graduation numbers In Higher Educational Institutions in Ukraine during the period 2012-2017 
Source: Developed by the authors based on the data provided by the Department of Education and Science of Dnipropetrovsk Regional State Administration.

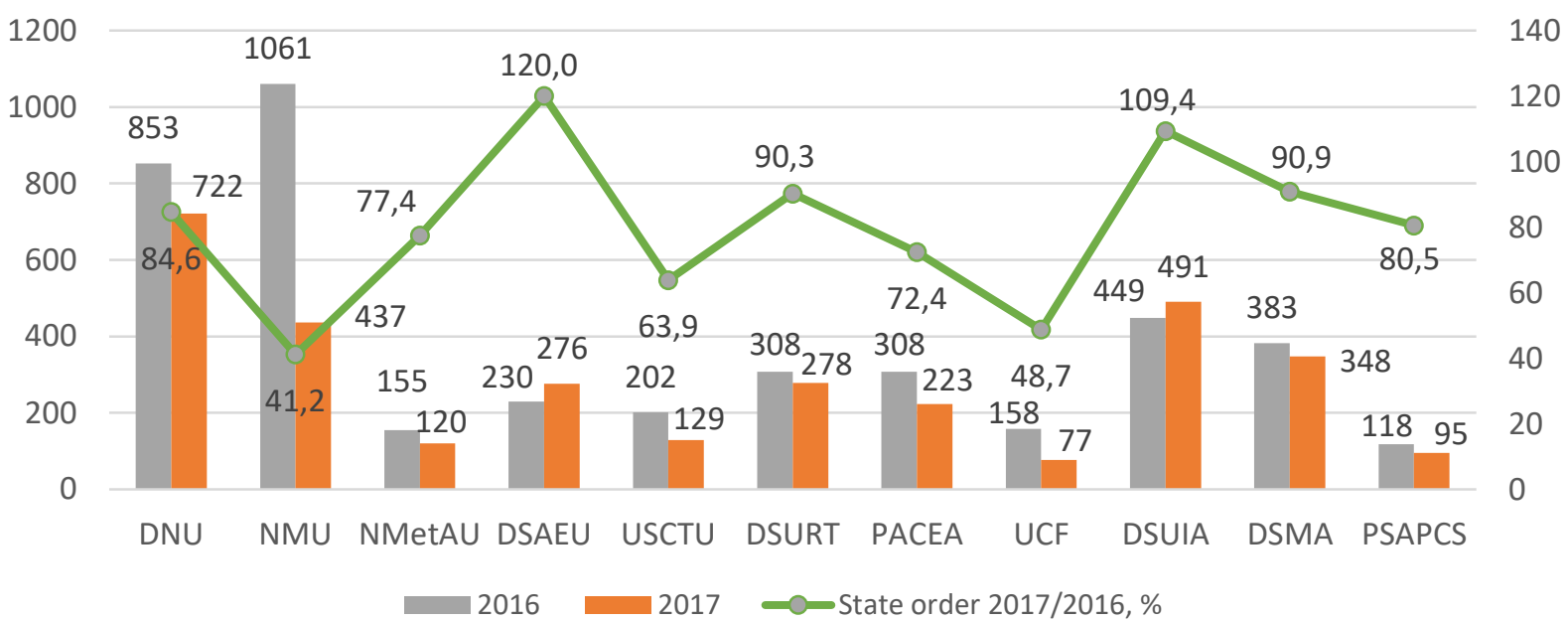

Figure 3. State order for HEls of Dnipro for educational level "Bachelor" in full-time and part-time forms of education in the period 2016-2017

penditures for funding of the Taras Shevchenko National University of Kyiv have grown by $23.9 \%$.

However, during the period 2012-2016, the number of enrolled students decreased, which is caused by the negative index of natural population growth since 1990 (Figure 2) and because of the intensification of the international academic mobility pushed by the opportunities for youth offered by foreign universities.

Despite the fact that the number of graduates with higher education degrees overtops the quantity of university entrants, the number of graduates decreased in the period 2012-2016. Positive dynamics and coming out of the population drop (so called "demographic hole") has started since 2017.

It should be noted that the number of HEIs has decreased in 2014, which was caused by the consequences of the socio-economic and political crisis in Ukraine. During the period 2015-2017, the number of HEIs in Ukraine did not change. We believe that the decrease of the students population is not a reason for reduction of the number of HEIs, but it is a factor encouraging universities to improve the quality of education and become more competitive (e.g., when the number of students in the group is not 35 , but 20-25 people, which allows to make learning process more effective).
Let's consider the results of university admissions campaign on the example of HEIs located in one of the biggest cities of Ukraine, the city Dnipro (the population of Dnipro is almost $1 \mathrm{mln}$. people). The amount of the state order (statistics of statefunded places) for universities in Dnipro in the period 2016-2017 is presented in Figure 3.

Analyzing the data on Figure 3, we see that in general the quantity of the state order for all public Higher Educational Institutions in Dnipro has declined. In particular, in 2017, the National Mining University (NMU) and the University of Customs and Finance (UCF) received only $41.2 \%$ and $48.7 \%$ of the state-funded places in comparison with 2016 and enrolled by $40 \%$ less students. However, there are some HEIs, where the state order grew in comparison with 2016: in Dnipropetrovsk State Agrarian and Economic University (DSAEU) - by 20\% and in the Dnipropetrovsk State University of Internal Affairs (DSUIA) (subordinated to the Ministry of Internal Affairs) - by $9.4 \%$.

Despite the increase of the budget expenditures for training specialists with higher education by HEIs of the III and IV accreditation levels, the number of state-funded places decreases annually: from 97 thousand in 2015 to 61 thousand in 2017. The Ministry made changes trying to make the mechanism of higher education funding in Ukraine more transparent, but unfortunately the idea of equality and fairness in distribution and 
allocation of state-funded places was distorted and failed. Its' effectiveness is questionable because of the fact that university entrants with high marks couldn't receive guarantees from the first sight (guarantees by their high exam results) in the state-funded place because of cancellation of the state order in the "unpopular" university chosen by them.

The regional coefficient, which increases the competition score of entrants, does not solve the problem substantially, because the majority of applications apply for the most powerful universities located in Kyiv. It occurs that the order is allocated to the economically strongest universities, some of them have separate targeted budget funding, so they are able to ensure students' enrolment in the licensed amounts even without any governmental support. Despite our respect to the idea of excellence and giving special support to the best research universities, we should ensure the variety of higher education landscape across the country and balanced development of its parts (regions). But examples of distribution and allocation of the state order among HEIs in Ukraine show how imbalanced and illogical it is, e.g.: from 65 statefunded places for the specialty 293 "International Law", 48 places are concentrated in one university, 43 of 49 state-funded places for the specialty 232 "Social Security" were divided among 4 Higher Educational Institutions, 132 of 191 places by the specialty 292 "International Economic Relations" were allocated at 5 universities. Such mechanism of distribution of public funding causes the concentration of the major share of government funding in the universities located in the capital city, which hampers fair and equal competition for regional universities even if they achieve good performance indicators and constantly increase their effectiveness. University applicants will go to HEIs where the state-funded places are provided, which will gradually destroy the universities located in the regions.

The second important issue besides the amounts and allocation of budgetary funds is its purposefulness. The question is how targeted the allocation of budget resources to finance the state order is? How much is returned to the state from the money invested in funding of state students' scholarships in the form of improved quality of em- ployees' work (public servants, employees of state enterprises, workers of public institutions and organizations), if there is no mechanism for monitoring graduates tracking, especially those who studied at the state-funded places and would have the obligation to work in the public sphere for several years? The is no practice anymore to appoint graduates directly to the positions in the public institutions (where needed), since entering the civil service is carried out on the basis of the competition (Article 21 of the Law of Ukraine "On Civil Service" dated Desember 10, 2015, No. 889-VIII). There are no openly published data and statistics on the need for training the specialists with higher education in various fields of the national and regional economy, it is unknown whether this information is considered as the basis for calculating the number of state-funded places within each specialty.

Thus, in order to ensure fair and equal conditions for all HEIs in Ukraine, we would propose to make significant changes to the model of public higher education funding in our country and to reform the mechanism of the state order.

First, it is necessary to calculate how much does the state order for the Bachelor student cost for the government, counted at their admission time (Table 2), using the formula:

$$
P V=F V \cdot \frac{1}{(1+r)^{n}},
$$

where $F V$ - future value of investment in $n$ years; PV - amount of investment; $r$ - interest rate (decimal fraction); $n$ - number of years in the calculation period.

$$
\begin{aligned}
& N P V=-20,000+(-20,000) \times \\
& \times D F[1 ; 15.43 \%]+(-20,000) \times \\
& \times D F[2 ; 15.43 \%]+(-20,000) \times \\
& \times D F[3 ; 15,43 \%]+(-20,000) \times \\
& \times D F[4 ; 15.43 \%]=-65,338 \mathrm{UAH},
\end{aligned}
$$

where $D F$ - discount factor.

As we see, the cost of training one Bachelor student, calculated at the time of admission in 2015 is UAH 63,365 , which was spent by the government. 
Table 2. The cost of a state-funded place per single applicant of educational level "Bachelor" (funding per 1 student)

\begin{tabular}{l|c|c|c}
\multicolumn{1}{c}{ Source: Developed by the authors based on the data of State Statistics Service of Ukraine (n.d.). Consumer price index (2012-2017). } \\
\hline \multicolumn{1}{c}{ Parameters } & $\mathbf{2 0 1 5}$ & $\mathbf{2 0 1 6}$ & $\mathbf{2 0 1 7}$ \\
\hline Number of a period & $-20,000$ & 1 & 2 \\
\hline $\begin{array}{l}\text { Cost of state-funded place, UAH } \\
\text { Consumer Price Index in education, related to the }\end{array}$ & 17.9 & $-20,000$ & $-20,000$ \\
previous year, \% & 16.5 & $-20,000$ \\
\hline $\begin{array}{l}\text { Consumer Price Index in education as average in the } \\
\text { period 2015-2017, \% }\end{array}$ & 15.43 & 11.9 \\
\hline
\end{tabular}

Such investment is often not remunerated: graduates who studied at the state-funded places rather prefer to work in private sphere instead of public or strategically important (but not financially attractive) private sphere, which may have an urgent need in good specialists. Private market is more attractive for the best graduates, while public institutions could not compete with private companies in salaries, social benefits, career perspectives, etc. Young people during or after graduation from the university may also go abroad, where they apply the acquired knowledge working for the foreign economy. As a consequence, the local and national public sector suffers from the lack of highly qualified human resources. And the government should develop and introduce relevant policy measures to encourage public sphere also by the mechanism of state order.

We would propose that public higher education funding could be organized within 3 pillars: the Targeted Government Funding (instead of the current model of state order), the Students Loan Fund, and the System of Research Funding (needs to be analyzed separately). Let us see how the targeted funding, which is going to be a transformed model of state order, and the Fund for student loans, can function.

In the proposed model, the Targeted Government Funding includes some streams of funding. First, the government (state) order is preserved in its present meaning, i.e. the government and governmental agencies "order" training specialists for their fields (institutions) as employers and pay for their training. Fully state-funded places will be ensured for universities who train specialists in regulated fields and civil service (e.g. military, police, emergency, border guards, etc.) and whose graduates have to serve in state institutions during the certain term fixed by the law. Training teach- ers and medical students is up to the wide public discussion (as they have no status of civil servants, as in other countries). In this case, the government and its agencies as employers will guarantee graduates' employment, and graduates will "compensate these investments" by their service working for these agencies. This model serves for attracting human capital in the strategic security areas and is relevant for Higher Education Institutions subordinated to the Ministry of Defence of Ukraine, the Security Service of Ukraine, the Ministry of Emergency of Ukraine, and others who train civil servants. Experts (Stadny, 2016) expressed the same idea. It will be the group of entrants with targeted referrals.

The second category of targeted state funding is grants for gifted young people who have the highest performance rate and high marks by the results of the External Independent Testing, who should be fully supported and rewarded for their excellence in further education path. The government policy in building human capital of Ukraine should be focused on encouraging talented young people to stay in the country and study in Ukrainian HEIs by their choice. The situation when persons with the highest performance rate drop out during the admission process is unacceptable and damaging for the future development and does not meet the national strategic interests. In this case, full government support and targeted funding (money after student) will also motivate other schoolchildren and young people to study better and harder in school. This type of targeted funding is offered for the first year of studying, after the first year, these students become eligible for the next category of targeted funding and compete equally with others. It will stimulate their further performance (unfortunately, high entrance rates do not guarantee good performance results and retention). 
Table 3. Initial data for calculating the cost of using target preferential state loan

Source: Developed by the authors based on the data of the State Statistics Service of Ukraine (n.d.), Consumer price index (2012-2017).

\begin{tabular}{|c|c|c|c|c|}
\hline Indicators & 2015 & 2016 & 2017 & 2018 \\
\hline Tuition fee (the cost of the contract), UAH & $-10,750$ & $-10,750$ & $-10,750$ & $-10,750$ \\
\hline Total cost of the contract to count interests, UAH & $-43,000$ & & & \\
\hline Total cost of the contract including interest, UAH & $-43,000$ & & & \\
\hline $\begin{array}{l}1 / 15 \text { share of the cost of the contract including interest, which } \\
\text { have to be returned, UAH }\end{array}$ & 2,867 & & & \\
\hline
\end{tabular}

The third group of targeted funding includes students who show the best performance results and they can be granted the government scholarship (state funding) on a competitive basis for one year. If they achieve very good results further, this scholarship can be awarded next year also. It should be stressed that this funding should be applicable only to high-ranked students within a specialty, which is considered in the amounts of funding for the field of study based on the national priorities and regional economic strategy. The number of targeted state-funded places will be calculated in proportion to the number of students' population in each Higher Education Institution, which will also contribute to creating equal conditions for all universities in their performance. But this process should be transparent and open, academic integrity must be a prerequisite to prevent manipulations and corruption in the learning process. This idea accumulates the proposal of the Ministry of Education and Science to introduce some coefficients for selected specialties that urgently need the qualified staff. We believe that the proposed mechanism would allow the government to stimulate the quality of education and encourage studying better by putting more efforts to responsible learning.

The fourth group of targeted funding is preferential categories of university entrants (full state support ensured), according to the definition of such groups by the current law (e.g. vulnerable groups of people).

The basic legal framework for student loans from the public funds has been created in Ukraine. The main regulation on student loans is the Decree of the Cabinet of Ministers of Ukraine (dated June 16, 2003, No. 916) "On Approval of the Procedure for Granting the Target State Loans for Higher Education". According to this Decree, "target state preferential loan for acquiring higher education in full-time and part-time forms of study, regard- less of the form of university ownership, can be received by young citizens of Ukraine under the age of 28 , who have successfully passed entrance examinations or who is studying at any year in higher educational institution; the amount of the loan is returned with a payment of 3\% per annum during 15 years from the twelfth month after graduation with the payment of one fifth of the total amount of the loan received and interest for its use annually". It should be noted that the loan is being given from the state budgetary funds. The amount of the loan is regulated both in public and private HEIs by the Ministry of Education and Science. Assuming that in the absence of state-funded places, when the government acts as "a sponsor", entrants will pay the full cost of education, the government can act "as a creditor", it is possible to calculate the cost of tuition for one bachelor. Let's assume that a rate of the loan is $0 \%$ (Table 3).

Using the Formula 1, we calculate the cost of training one bachelor student if target state preferential loan is being granted (Table 4).

Thus, if the cost of the loan was UAH 10,750 per one year for four years, with an average interest rate (Consumer Price Index in education) of $15.43 \%$, the student should start paying from 2019 for the next 15 years per $1 / 15$ of the principal of the loan with interest (in this case $0 \%$ ) in the amount of 2,867 UAH, per year. Calculating the invested and received funds at the moment of admission to the university, we determine that the government spends 23,646 UAH.

$$
\begin{aligned}
& N P V=-10,750+(-10,750) \times \\
& \times A F[3 ; 15.43 \%]+3,082 \times \\
& \times A F[15 ; 15.43 \%] \times \\
& \times D F[3 ; 15.43 \%]=-24,446
\end{aligned}
$$

where $A F$ - annuity factor, $D F$ - discount factor. 
Table 4. The cost of education per a single bachelor student if target state preferential loan is granted

Source: Developed by the authors based on the data of the State Statistics Service of Ukraine (n.d.), Consumer price index (2012-2017).

\begin{tabular}{|c|c|c|c|c|c|}
\hline Authors' proposal & 2015 & 2016 & 2017 & 2018 & 2019-2033 \\
\hline Period & 0 & 1 & 2 & 3 & 4 \\
\hline Tuition fee (cost of contract), UAH & $-10,750$ & $-10,750$ & $-10,750$ & $-10,750$ & \\
\hline $\begin{array}{l}\text { Consumer Price Index in education as average for } \\
\text { the period 2015-2017, \% }\end{array}$ & 15,43 & & & & \\
\hline Cash flows, UAH & $-10,750$ & $-10,750$ & $-10,750$ & $-10,750$ & $15 \cdot 2.867$ \\
\hline Net present value, UAH & $-24,446$ & & & & \\
\hline
\end{tabular}

Comparing the state budget expenditures in case of funding of the state order (UAH 65,338 ) and the cost of a state preferential loan (UAH 24,446), we should assess the feasibility and expediency of state order for training specialists with higher education for the government. In the second case, the government does not receive profits, but reduces losses in comparison with the first option. It proves that there is a legal and social prerequisite for considering the government as the founder of the students loan fund. Students loans introduced on a large scale will contribute to strategic goals of the social and economic development in terms of the national and regional perspective. It will also decrease the number of those who pay tuition fees and inflated prices for contract-based study. The market of education services will become more competitive and transparent. Moreover, in case of students' loans, or paying tuition fees, graduates don't have the obligation to work in the public economy sector, or governmental agencies or at civil service for a fixed term, giving entrants a free choice but keeping strategic national priorities.

The proposed mechanism of student loans is also very flexible and allows exemptions and reductions. Several options are possible: a person can be exempted from the loan and interests payment if employed in the public economy after graduation during 5 years (the idea to stimulate public sector economy), a person can get compensation of interest for using the education loan, the principal of the loan, or the full value of the loan (principal of the loan with interest) by the decision of the employer (can be fixed in the contract). Lending to non-priority specialties can be carried out under other conditions, for example, using a higher interest rate for the loan or using larger parts of its payment.

The created model opens opportunity for small and medium enterprises to attract specialists by the additional social benefits, for big enterprises, it allows to create more competitive job proposals market for young people and will allow to create partnerships with HEIs, develop study programs and cooperate closer and make higher education meet the labor market requirements. Companies can get an additional tool in their human resources policy and create their individual policies; packages targeted for different specialists and stimulate their professional activity. This model will also help university entrants to choose their study programs more thoroughly and more responsibly, but not randomly as it happens today, when the only criteria is the state-funded place.

Summing it up, the mechanism of public higher education funding proposed by authors (see Figure 4) corresponds with the Constitutional principles and values ensuring accessible and quality education on a competitive basis and state support for development of human capital, as well as balanced and sustainable development of Ukraine as the state and its territories. This model meets interests of all categories of entrants and students: gifted applicants and successful students, applicants of preferential categories and students who trained according to targeted referrals. Moreover, this mechanism will ensure more sustainable regional development in its educational and economic spheres combined, not only encouraging quality of education, but also raising possibilities for social support of the young labor force at the labor market both on the national and regional levels. 


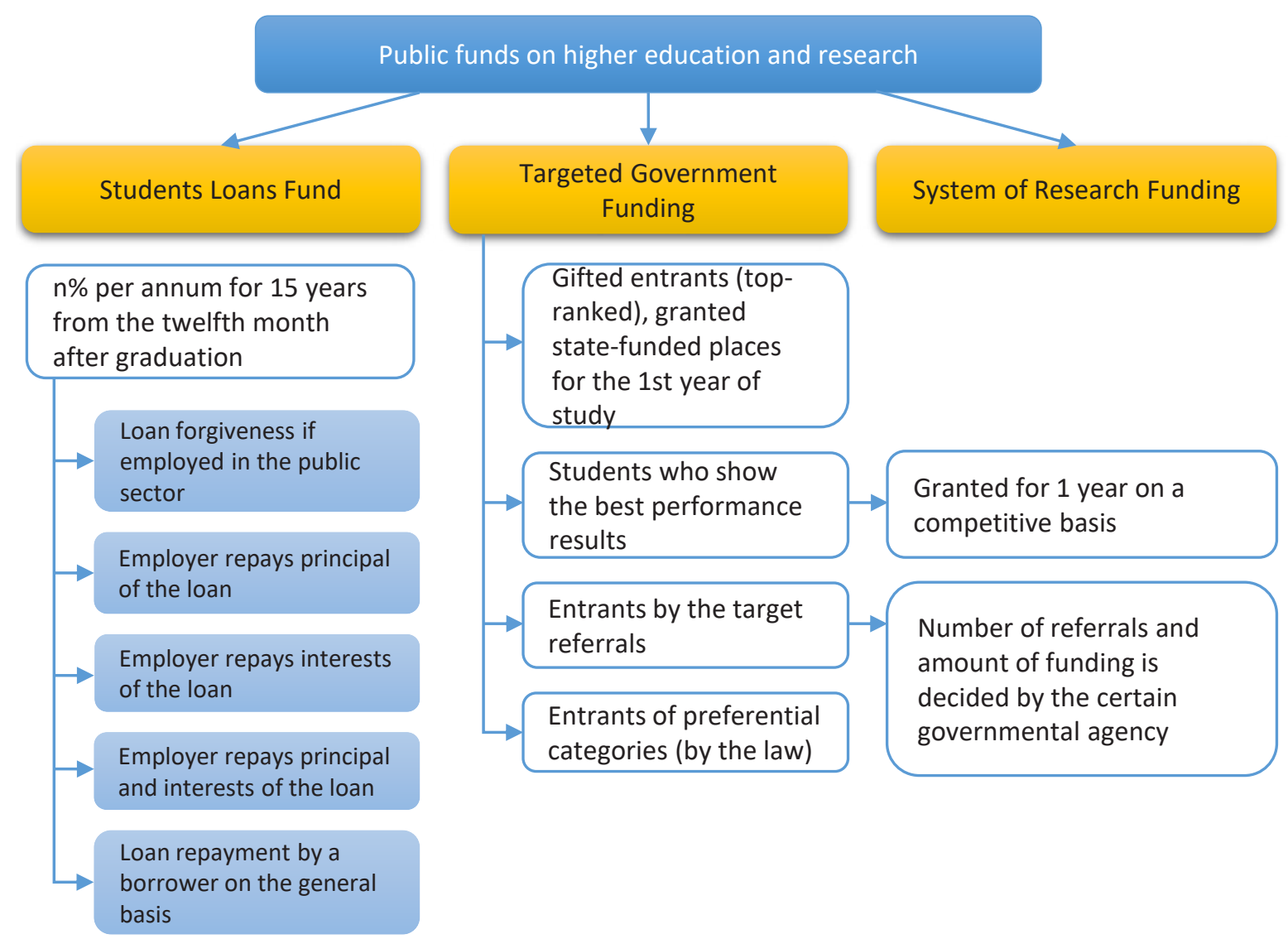

Figure 4. Mechanism of public higher education funding in Ukraine: authors' proposal

\section{CONCLUSION}

The issue of public higher education funding is currently one of the biggest challenges in all European countries and in the developing ones, in Ukraine as well. The budget expenditures on higher education in Ukraine increased during last 6 years in absolute amounts from UAH 15,1 billion to UAH 20,3 billion, while the number of the state-funded places for training specialists with higher education decreased from 97 thousand in 2015 to 61 thousand in 2017. A significant reduction of the public funding is observed in Higher Education Institutions on the local level (e.g. state order decreased in universities in Dnipro), which is caused by the general decline of the numbers of students' population and quantity of applicants in many universities.

By calculating the net present value of the cost of state-funded place (funding per student) in 2015, it was found out that the government spends UAH 65,338 that are often not remunerated. Graduates would not prefer to be employed in the public sector because of the weak competitive ability of public institutions in terms of salary and social benefits, and lack of relevant measures to attract young human resources. The lack of the mechanism for tracking university graduates employment hampers strategic forecasts for human capital development, as well as quality analysis of the labor market in its connection with the higher education sector.

Experts and good practices of some leading countries prove the need for establishing, introducing and promoting the schemes of public loans for students with a wide range of reasons to forgive. The cost of a student loan, which can be given from the state budget funds, can be less expensive than state-funded 
place (UAH 24,446). This proves higher efficiency of the proposed mechanism and feasibility of urgent reforming of the existing model of public funding concentrated on the state order formula.

A new model of public higher education funding was proposed, based on the current legislation and good practices. The model consists of three main pillars: the Targeted Government Funding, the Students Loan Fund, and the System of Research Funding. Targeted government funding together with students loans system will replace the current model of allocation of state-funded places.

Summing it up, we should stress that a new model of public higher education funding meets the social and economic needs, and it is quite feasible and reasonable for Ukrainian political and financial realities. The proposed model can increase the efficiency of budget expenditures, on the one hand, and ensure open and equal competition for all Higher Education Institutions, on the other hand. It will encourage the employment of the best graduates in the public sector and boost close cooperation between higher education and the labor market.

\section{REFERENCES}

1. Act on Higher Education and Science, The Law of Republic of Poland on July 20, 2018. Retrieved from http://orka.sejm.gov.pl/ proc8.nsf/ustawy/2446_u.htm

2. Athena (2015). University Autonomy in Ukraine: Analysis \& Roadmap 2012-2015. Retrieved from https://athena-tempus.eu/ images/ATHENA\%20analysis\%20 and\%20roadmap\%20for\% 20 UKRAINE.pdf

3. Bagmet, M., \& Liakhovets, O. (2017). Towards the European Union's Education Standards: Expectations of the Ukrainians. Economics and Sociology, 10(2), 191-206. http:// dx.doi.org/10.14254/2071789X.2017/10-2/14

4. Carton, G., McMillan, C., \& Overall, J. (2018). Strategic capacities in US universities the role of business schools as institutional builders. Problems and Perspectives in Management, 16(1), 186-198. http://dx.doi. org/10.21511/ppm.16(1).2018.18

5. Cohen, E., Davidovitch, N. (2015). Higher education between government policy and free market forces: The case of Israel. Economics and Sociology, 8(1), 258-274. http:// dx.doi.org/10.14254/2071789X.2015/8-1/20

6. Decree of the Cabinet of Ministers of Ukraine. On Approval of the
Procedure for Granting the Target State Loan for Higher Education (2003, June 16). Retrieved from http://zakon3.rada.gov.ua/laws/ show/916-2003-\%D0\%BF

7. Estermann, T., \& Pruvot, E. B. (2011). Financially Sustainable Universities II. Brussels: European University Association. Retrieved from http://eua.be/Libraries/ publications-homepage-list/Financially_Sustainable_Universities_II.pdf? sfvrsn=2

8. Eurydice (2008). Higher education governance in Europe. Policies, structures, funding and academic staff. Brussels: Eurydice, European Commission, Education and Culture DG.

9. Federal Student Aid (n.d.). Public Service Loan Forgiveness. Retrieved from https://studentaid. ed.gov/sa/repay-loans/forgivenesscancellation/public-service

10. Guille, M. (2002). Students Loans in Europe An Overview. European Journal of Education, 37(4), 417-431. Retrieved from https://www.jstor.org/ stable/1503809?seq=1\#page_scan_ tab_contents

11. Human Development Statistical Tables - 2016. Retrieved from http://hdr.undp.org/en/data

12. Jongbloed, B. (2004). Funding Higher Education: options, tradeoffs and dilemmas (Paper for Ful- bright Brainstorms - New Trends in Higher Education). CHEPS. Netherlands: University of Twente. Retrieved from https://www.pravo. unizg.hr/_download/repository/ Funding_higher_education.pdf

13. Kwiek, M. (2006). The University and the State: A Study into Global Transformations (424 p.). Peter Lang Publishing.

14. Lepori, B. (2007). Funding Models of Swiss Universities of Applied Sciences. International Experiences and Options for the Swiss case (Report on behalf of the Rector's Conference of Swiss Universities of Applied Sciences). Retrieved from https://www.swissuniversities.ch/ fileadmin/swissuniversities/Dokumente/Kammern/Kammer_FH/ Publikationen/UAS_funding.pdf

15. Nikolayev, Ye. B. (2017). Higher Education in Ukraine: Agenda for reforms (KAS Policy Paper). Kyiv: Konrad-Adenauer-Stiftung Ukraine Office.

16. O'Leary, S. (2015). The Role of Enterprise and Entrepreneurship within Higher Education and Effective Economic Governance across Central and Eastern Europe. Economics and Sociology, 8(2), 143-153. http:// dx.doi.org/10.14254/2071789X.2015/8-2/11

17. Pruvot, E. B., Claeys-Kulik, A. L., \& Estermann, T. (2015). Strategies for Efficient Funding of 
Universities in Europe. In The European Higher Education Area (pp. 153-168). Retrieved from https://link.springer.com/chapter/10.1007/978-3-319-20877-0_11

18. Rybchanska, Kh. (2016). Assessment of financial leverage for higher education. Finance, accounting, banks, 1, 276-287.

19. Salmi, J. (2003). Student Loans in an International Perspective: The World Bank Experience (LCSHD paper series No. 44). Washington, DC: World Bank. Retrieved from http://documents.worldbank.org/ curated/en/149001468765578181/ Student-loans-in-an-international-perspective-The-World-Bankexperience

20. Satsyk, V. (2014).

Детерминанты глобальной конкурентоспособности университетов: в поисках эффективной стратегии развития высшего образования на Украине [Determinanty globalnoy konkurentosposobnosti universitetov: $\mathrm{v}$ poiskakh effektivnoy strategii razvitiya vysshego obrazovaniya na Ukraine]. Voprosy obrazovaniya, 1, 134-161.

21. Savchenko, I., \& Chumak, O. (2017). Modernization of the state mechanism of higher education finding. In Theory and practice of public administration: collection of scientific articles (pp. 56-72). Kharkiv Regional Institute of Public Administration.

22. Shevchuk, A. (2014). Use of foreign experience to manage the development of regional educational systems in Ukraine. Problems of the economy, 3, 164-170.

23. Soobramoney Penceliah, Samkele V. M. Konyana, \& Mandusha Maharaj (2016). The choice of public universities in a restructured and transforming Higher Education landscape: a student perspec- tive. Problems and Perspectives in Management, 14(3-1), p. 276282. http://dx.doi.org/10.21511/ ppm.14(3-1).2016.14

24. Stadny, Y. (2016). Conceptual Model of Performance-Based Funding of Higher Education Institutions in Ukraine. Retrieved from https://cedos.org.ua/en/articles/ kontseptualna-model-derzhavnoho-finansuvannia-vnz-za-rezultatamy-diialnosti

25. State Statistics Service of Ukraine (n.d.). Consumer price index (2012-2017). Retrieved from http://www.ukrstat.gov.ua//

26. State Statistics Service of Ukraine (n.d.). Higher educational institutions (2012-2017). Retrieved from http://www.ukrstat.gov.ua//

27. State Treasury Service of Ukraine (n.d.). Expenditures on the program classification of expenditures and lending of the state budget. Retrieved from http://www.treasury. gov.ua/

28. The European University Association (2018). Public Funding Observatory. Retrieved from http:// eua.be/activities-services/projects/ eua-online-tools/public-fundingobservatory-tool.aspx

29. The Global Human Capital Report - 2017. Retrieved from http://www3.weforum.org/docs/ WEF_Global_Human_Capital_ Report_2017.pdf

30. The law of Ukraine. On Civil Service (2015, December 10). Retrieved from http://zakon3.rada. gov.ua/laws/show/889-19

31. The law of Ukraine. On Higher Education (2014, July 01). Retrieved from http://zakon3.rada. gov.ua/laws/show/1556-18

32. The Ministry of Economic Development and Trade of Ukraine (2018). The Ministry of Economic Development has proposed to change the mechanism of the state order for the current and next academic year. Retrieved from http://me.gov.ua/News/ Detail?lang $=$ uk-UA\&id $=955 f 5 \mathrm{dc} 7-$ 9807-46d2-a90e-

d639e390d1aa\&title=MinekonomrozvitkuZaproponuvaloZminitiMekhanizmDerzhavnogoZamovlenniaNaPotochniiTaNastupniiNavchalniiRik

33. The World Bank (2018). New country classifications by income level: 2018-2019. Retrieved from http://blogs.worldbank.org/opendata/new-country-classificationsincome-level-2018-2019

34. Velychko, O., \& Velychko, L. (2018). Matrix structures in management of quality of educational and scientific work of Ukrainian universities. Problems and Perspectives in Management, 16(1), 133144. http://dx.doi.org/10.21511/ ppm.16(1).2018.13

35. Woźnicki, J. (2017). Postulat selektywnego charakteru deregulacji w szkolnictwie wyższym. Nauka i Szkolnictwo Wyższe, 2(50), p. 91-105. https://doi.org/10.14746/ nisw.2017.2.4

36. Woźnicki, J. (Ed.) (2013). Financing and Deregulation in Higher Education. Warsaw: Institute of Knowledge Society. Retrieved from http://pbc.biaman.pl/Content/27641/Financing_wersja_ostat.pdf

37. Zatonatska, Т. (2012). Зарубіжний досвід фінансування розвитку освіти: перспективи застосування в Україні [Zarubiznhyi dosvid finansuvannia rozvytku osvity: perspektyvy zastosuvannia v Ukraini]. Bulletin of the Taras Shevchenko National University. Economy, 139, 36-39. Retrieved from http://bulletineconom.univ.kiev.ua/wp-content/ uploads/2015/11/139_10.pdf 